\title{
Dakwah Pada Masyarakat Daerah Terpencil: Metode Da'wah bi al-Hal Sebagai Upaya Meningkatkan Taraf Kehidupan Mad'u
}

\author{
Muhammad Ahnu Idris \\ Pascasarjana UIN Sunan Ampel Surabaya \\ putra.nusantarasta@gmail.com
}

\begin{abstract}
Abstrak
This article discusses methods of da'wah bi al-things in order to improve the lives of people in remote areas. Qualitative analysis, with the results of this paper was elaborated in the form of discussion based on literature and existing data. This topic is based on the assumption of reality in a society that assumes that the Da'wah only as a religious lecture, and lack of attention by activist preaching about the importance of this method to change the condition of a remote community have a low level of education, economic level intermediate down, less master SCIENCE and TECHNOLOGY. These themes became important, as the progress and setbacks of Islamic Da'wah activities largely determined by which become the duty of every muslim.
\end{abstract}

Keyword: dakwah, methods of da'wah, da'wah bi al-things, people in remote areas

\section{Pendahuluan}

Islam adalah agama yang berisi petunjuk-petunjuk supaya manusia secara individual menjadi lebih baik, beradab dan berkualitas, selalu berbuat baik sehingga mampu membangun sebuah peradaban yang maju, sebuah tatanan yang manusiawi dalam arti kehidupan yang adil, maju, bebas dari berbagai ancama, penindasan dan berbagai kekhawatiran. Untuk mencapai semua itu, Islam memiliki konsep yang namanya dakwah. ${ }^{1}$

Dakwah merupakan kewajiban bagi setiap muslim di manapun, kapanpun, dan dalam kondisi apapun, sebagaimana telah dilakukan oleh sahabat-sahabat Nabi, baik sebagai pejabat, pedagang, prajurit, pegawai kecil, bahkan oleh seorang bekas budak yang dimerdekakan seperti Bilal bin Rabbah. ${ }^{2}$

1 Rizka Prasti, "Dakwah Melalui Media Radio (Analisis Pogram Cahaya Pagi di Radio Alaikassalam Sejahtera Jakarta)", (Skripsi-UIN Syarif Hidayatullah, Jakarta, 2010 M./1432 H.), 1.

2 Yunus Hanis Syam \& Muafi, Manajemen Dakwah: Dakwah dengan Tulisan Sebuah Peluang (Yogyakarta: Panji Pustaka, 2007), 2. 
Jalan ini (baca: dakwah) merupakan satu bagian yang pasti ada dalam kehidupan umat beragama. Dalam ajaran agama Islam, ia merupakan suatu kewajiban yang dibebankan oleh agama kepada pemeluknya, yang berisi seruan kepada keinsyafan, atau mengubah situasi kepada situasi yang lebih baik dan sempurna, baik terhadap pribadi maupun masyarakat. ${ }^{3}$

Dengan demikian, Islam sebagai agama dakwah selalu mendorong umatnya untuk selalu aktif melakukan kegiatan dakwah. Kemajuan dan kemunduran umat Islam, sangat berkaitan erat dengan kegiatan dakwah yang dilakukannya. Tak diragukan lagi bahwa ajaran tentang dakwah merupakan bagian integral dalam Islam. Di samping dituntut untuk hidup secara islami, setiap muslim juga dituntut untuk menyebarkan ajaran Islam ke seluruh umat manusia. Dengan kegiatan dakwah ini, Islam dapat menyebar dan diterima di seluruh belahan dunia. ${ }^{4}$

Selama ini, banyak orang memahami bahwa dakwah hanyalah aktifitas mengajak dan menyeru yang dikonotasikan pada penyampaian pesan berupa ayat-ayat dan hadists saja. Ketika seseorang melakukan kebaikan, tanpa dibubuhi dengan ayat-ayat al-Qur'an dan Hadits yang berbahasa Arab tidak dianggap dakwah. Padahal, dalam kondisi masayarakat yang jenuh dengan materi dakwah bermuatan motivasi, hukuman dan ganjaran tanpa adanya jalan keluar yang konkret, ditambah lagi tidak meratanya program pembangunan yang dilaksakan pemerintah, maka masyarakat menjadi pemalas, pasif, dan menjadi bingung terhadap ulama dan umara'. ${ }^{5}$

Maka dari itu, sudah saatnya para ulama mengembangkan suatu bentuk dakwah yang memberikan solusi bagi permasalahan umat, dakwah yang tidak hanya memberikan motivasi, tetapi dakwah yang memberikan contoh konkret dalam memenuhi kebutuhan umat. Dakwah bi al-hal merupakan model dakwah yang sesuai dikembangkan dalam pembangunan atau pengembangan masyarakat, mengingat pengembangan masyarakat menuntut adanya kerja dan karya nyata. ${ }^{6}$

Artinya, seorang muslim (kususnya dai) harus peka terhadap kondisi masyarakat yang ada di sekitarnya, dan berkewajiban merubah kondisi itu menjadi lebih baik. ${ }^{7}$

\footnotetext{
${ }^{3}$ Wisri, "Dakwah Pada Masyarakat Terasing: Studi Analisis tentang Tipologi Mitra Dakwah "Suku Anak Dalam" di Taman Nasional Bukit Dua Belas Jambi", Jurnal Lisan Al-Hal, Vol. 6, No. 1, (Juni, 2014), 36.

${ }^{4}$ Fathur Razi, "NU dan Kontinuitas Dakwah Kultural", Jurnal Komunikasi Islam, Vol. 1, No. 2, (Desember, 2011), 62.

${ }^{5}$ Faizal, "Dakwah bil-Hal Dalam Perspektif Al-Qur'an", Jurnal Ilmu Dakwah dan Pengembangan Komunitas, Vol. VIII, No. 2, (Juli, 2013), 3.

${ }^{6}$ Ibid.

${ }^{7}$ Muhammad Abduh, Komitmen Dai Sejati, terj. Asep Sobri (Jakarta: Al-I'tishom Cahaya Umat, 2007), 146.
} 
Maka berangkat dari kondisi inilah, penulis berusaha memaparkan tentang da'wah bi al-hal dalam rangka mengembangkan kehidupan masyarakat terpencil guna meningkatkan taraf kehidupan mereka.

\section{Dakwah dan Metode Dakwah}

\section{Dakwah}

Kata "dakwah" merupakan kata serapan dari bahasa Arab "da'wah". Kata ini merupakan bentuk mashdar (kata benda) dari fi'il (kata kerja) "da'a", "yad'u", yang artinya: mengundang, memanggil atau menyeru. ${ }^{8}$

Jum'ah Amin Abdul Aziz memberikan beberapa arti pada kata dakwah: memanggil, mengajak pada sesuatu; mengundang; upaya memengaruhi orang lain kepada suatu madzhab atau agama dan, doa. ${ }^{9}$

Arti kata Dakwah seperti ini banyak dipergunakan dalam ayat-ayat alQuran, antara lain:

a. Surat al-Baqarah, 2:186 yang artinya:

"Dan apabila hamba-bamba-Ku bertanya kepadamu tentang Aku, maka (jawablah), bahwasanya Aku adalah dekat. Aku mengabulkan permohonan orang yang berdoa apabila ia memohon kepada-Ku.” (QS. al-Baqarah [2]: 186)

b. Ali Imran, 3:104

"Dan hendaklah ada di antara kamu segolongan umat yang menyeru kepada kebajikan, menyurub kepada yang ma'ruf dan mencegah dari yang munkar; merekalah orang-orang yang beruntung." (QS. Ali Imran [3]: 104)

c. Surat al-Rum, 30:25

"Dan di antara tanda-tanda kekuasaan-Nya ialah berdirinya langit dan bumi dengan iradab-Nya.Kemudian apabila Dia memanggil kamu sekali panggil dari bumi, seketika itu (juga) kamu keluar (dari kubur).” (QS. al-Rum [30]: 25)

d. Al-Mu'min, 40:43

"Sudah pasti bahwa apa yang kamu seru supaya aku (beriman) kepadanya tidak. dapat memperkenankan seruan apapun baik di dunia maupun di akbirat. Dan sesunggubnya kita kembali kepada Allah dan sesunggubnya orang-orang yang melampani batas, mereka itulah pengbuni neraka." (QS. al-Mu'min [40]: 43)

Tidak hanya itu, menurut al-Quran kata dakwah selain digunakan dalam arti mengajak kepada kebaikan, kata dakwah juga digunakan dalam arti mengajak kepada kejelekan. ${ }^{10}$ Sementara dalam bentuk isim, kata dakwah berarti seruan dan permohonan, sebagaimana penjelasan di atas.

\footnotetext{
8 Ahmad Warson Munawwir, Al-Munawnir: Kamus Arab-Indonesia. (Surabaya: Pustaka Progresif, 1984), 438-439.

9 Jum'ah Amin Abdul Aziz, al-Da'wah: Qawaid wa Ushul. (Alexandria: Dar al-Da'wah, 1999 M./1419 H), 17.

${ }^{10}$ Aswadi, Dakwah Progresif Perspektif Al-Qur'an. (Sidoarjo: Dwiputra Pustaka Jaya, 2016), 31.
} 
Bila dilihat dari segi penggunaannya, beberapa kata dakwah dalam ayatayat tersebut di atas, kesemuanya lebih tertuju pada ajakan kebaikan, terutama surat Ali Imran ayat $104 .^{11}$

Ali Aziz, kurang lebih ada sepuluh ayat al-Quran yang menjelaskan tentang arti kata dakwah: ${ }^{12}$ mengajak dan menyeru, baik kepada kebaikan maupun kemusyrikan; kepada jalan surga atau ke neraka (al-Baqarah, 221); doa (Ali Imran, 38); mendakwa atau menganggap tidak baik (Maryam, 91); mengadu (al-Qamar, 10); memanggil atau panggilan (al-Rum, 25); meminta (Shad, 51); mengundang (al-Qashash, 25); malaikat Israfil sebagai penyeru (Thaha, 108); panggilan nama atau gelar (al-Nur, 63); anak angkat (al-Ahzab, 4)

Secara etimologis, Aswadi memaparkan beberapa pendapat tokoh sebagai berikut: ${ }^{13}$

1) Al-Bahy al-Khulliy mengatakan bahwa dakwah adalah memindahkan suatu situasi manusia kepada situasi yang lebih baik;

2) Muhammad mengistilahkan dakwah dengan ishlah yaitu memperbaiki keadaan kaum muslimin dan memberi petunjuk kepada orang-orang kafir untuk memeluk Islam;

3) Syekh Ali Mahfudz mengintrodusir pengertian dakwah yaitu: memengaruhi manusia untuk berbuat kebajikan dan memperoleh hidayah, memerintah kepada yang ma'ruf dan mencegah dari berbagai tindakan munkar supaya mendapat kebahagiaan dunia dan akhirat;

4) Thoha Yahya Omar mendefinisikan dakwah: mengajak manusia secara bijaksana dengan jalan yang benar sesuai dengan perintah Tuhan untuk kemaslahatan dan kebahagiaan mereka di dunia dan akhirat;

5) Abu Bakr Zakariya mengatakan, dakwah adalah usaha para ulama dan orang-orang yang memiliki pengetahuan tentang agama Islam dengan memberi pengajaran kepada masyarakat tentang hal-hal yang dapat menyadarkan mereka terhadap urusan keagamaan dan keduniaannya sesuai dengan kemampuan yang dimiliki.

Berbeda dengan para ahli di atas, M. Natsir (dalam Mubasyaroh: 2013) lebih menekankan dakwah pada persoalan penyampaian pesan. Ini terlihat pada pernyataan di artikel lepasnya yang berjudul "Kalimat Hak Lebih Tajam Dari Pedang". Menurutnya, kewajiban da'i, muballigh, dan ulama tidak sebatas berfatwa atau memvonis bahwa komunis itu haram. Orang awampun mengatakan bahwa komunis itu jahat. Kewajiban umat Islam ialah

\footnotetext{
${ }^{11}$ Ibid.

12 Moh. Ali Aziz, Ilmu Dakwah (Jakarta: Kencana, 2016), 6-9.

${ }^{13}$ Aswadi, Dakwah Progresif, 32-33.
} 
mengemukakan alternatif dalam menghadapi sistem komunis itu, mengemukakan alternatif yang baik untuk menghadapi yang buruk. ${ }^{14}$

Selain beberapa pengertian di atas, dakwah juga bisa diartikan usaha atau aktivitas dengan lisan atau tulisan dan lainnya yang bersifat menyeru, mengajak, memanggil manusia lainnya untuk senantiasa taat kepada Allah demi kemaslahatan dan kebaikannya di dunia dan akhirat. ${ }^{15}$

Dengan demikian, maka dakwah dapat diartikan sebagai: pertama, memberikan tuntunan dan pedoman serta jalan hidup yang seharusnya dilalui untuk memperoleh petunjuk; kedua, memperbaiki keadaan seseorang atau masyarakat dari satu situasi ke situasi lain yang lebih baik; tiga, memberikan pengharapan akan sesuatu nilai agama Islam yang didakwahkan sehingga bisa dirasakan oleh orang lain tentang kebutuhan yang sangat vital dalam kehidupannya. ${ }^{16}$

Masih berkenaan pengertian dakwah, ada 38 ahli yang memberikan pengertian berbeda terhadap kata dakwah yang secara umum menunjuk pada kegiatan yang bertujuan perubahan positif dalam diri manusia. Perubahan positif ini adalah meningkatnya kadar keimanan seseorang. Karena tujuannya baik, maka dakwah harus dilakukan dengan baik pula. Secara singkat, dakwah bisa diartikan "kegiatan peningkatan iman menurut syariat Islam". ${ }^{17}$

\section{Metode Dakwah}

Dalam rangka menyampaikan pesan-pesan agama melalui dakwah, ada beberapa prinsip yang dapat dijadikan pegangan oleh dai. Prinsip-prinsip tersebut adalah: nahiyah (ناحية) atau pendekatan; manbaj (منهج) atau strategi;

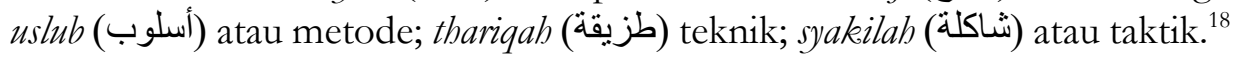
Jika kelima prinsip tersebut dikaitkan, maka pendekatan adalah langkah awalnya. Segala permasalahan bisa dilihat dan dipahami dari sudut pandang tertentu. Sudut pandang inilah yang dinamakan "pendekatan". Pendekatan melahirkan sebuah "strategi" (semua cara untuk mencapai tujuan yang ditetapkan). Setiap strategi menggunakan beberapa "metode"; dan "metode" ini membutuhkan "teknik" (cara yang lebih spesifik dan lebih operasional). Selanjutnya, setiap "teknik" membutuhkan "taktik" (cara yang lebih spesifik lagi dari "teknik"). Masing-masing istilah tersebut harus bergerak sesuai ketentuan yang ditetapkan. Ada ketentuan umum yang diikuti oleh semua

\footnotetext{
${ }^{14}$ Mubasyaroh. "M. Natsir dan Pandangannya Tentang Dakwah Dalam Buku Fiqhud Dakwah", At-Tabsyir, Vol. 1, No. 2, (Juli-Desember, 2013), 152.

${ }^{15}$ Edy Priyanto, "Dakwah dan Kesalehan Sosial: Kiprah Dakwah Roostien Ilyas" (SkripsiUIN Syarif Hidayatullah, Jakarta, 1436 H./2015 M.), 14

16 Aswadi, Dakwah Progresif, 33.

17 Aziz, Imu Dakwah, 11-19.

18 Aziz, Imu Dakwah, 346.
} 
istilah dan ada pula ketentuan khusus yang brlaku untuk suatu istilah tertentu. Ketentuan inilah yang kemudian dinamakan "prinsip". ${ }^{19}$

Meskipun pada bagian ini penulis akan membahas tentang kata "metode", tapi pemaparan prinsip-prinsip ini dirasa perlu, karena tidak sedikit kalangan yang masih merasa sulit membedakan antara istilah-istilah pada kelima pinsip tersebut. ${ }^{20}$

Metode merupakan kata serapan berasal dari dua kata yaitu "meta" (melalui) dan "hodos" (jalan, cara). Dengan demikian, dapat artikan bahwa metode adalah cara atau jalan yang harus dilalui untuk mencapai suatu tujuan. Sumber yang lain menyebutkan bahwa metode berasal dari bahasa Jerman methodicay artinya ajaran tentang metode. Dalam bahasa Yunani metode berasal dari kata methodos artinya jalan. Secara terminologi metode berarti cara yang telah diatur dan melalui proses pemikiran untuk mencapai suatu maksud. ${ }^{21}$

Partanto (dalam Aziz) mengartikan kata "metode" sebagai cara sistematis dan teratur untuk melaksanakan sesuatu atau cara kerja. ${ }^{22}$

Dengan demikian, "metode dakwah" dapat diartikan: cara-cara yang ditempuh oleh dai dalam dakwahnya atau tata cara mengimplementasikan manahij al-da'wah (strategi-strategi dakwah). ${ }^{23}$

Scara garis besar, bentuk dakwah dibagi tiga: da'wah bi al-lisan (dakwah lisan), da'wah bi al-qalam (dakwah tulis), da'wab bi al-bal (dakwah tindakan). Dengan demikian, maka metode dakwah diklasifikasikan menjadi 6: 1) metode ceramah; 2) metode diskusi; 3) metode konseling; 4) metode karya tulis; 5) metode pemberdayaan masyarakat; dan 7) metode kelembagaan. ${ }^{24}$

Senada dengan Aziz, Suisyanto juga membagi dakwah menjadi tiga. Menurutnya, pembagian dakwah menjadi tiga itu merujuk kepada apa yang dilakukan Rasulullah dalam upaya penyampaian ajaran Islam (dakwah): yaitu lisan, tulisan dan perbuatan. ${ }^{25}$

Dari metode-metode dakwah di atas, penulis akan menguraikan bentuk da'wah bi al-hal sebagai upaya mengangkat taraf kehidupan masyarakat.

19 Ibid, 347.

${ }^{20} \mathrm{Ibid}, 346$.

${ }^{21}$ Novaili. "Metode Dakwah Penyuluh Agama Islam Dalam Mewujudkan Keluarga Sakinah Terhadap Pasangan Calon Suami Istri Di Kantor Urusan Agama (KUA)", Konseling Religi, Vol. 6, No. 2, (Desember, 2015), 408.

22 Aziz, Ilmu Dakwah, 358.

${ }^{23}$ Muhammad Abu al-Fath al-Bayanuni, al-Madkhal ila 'Tlmu al-Da'wah. (Beirut: Mu'assasah alRisalah, 2001 M./1422 H.), 47.

${ }^{24}$ Aziz, Ilmu Dakwah, 359-383.

${ }^{25}$ Suisyanto. "Dakwah bil-Hal (Suatu Upaya Menumbuhkan Kesadaran dan Mengembangkan Kemampuan Jamaah)", Aplikasia, Vol. 3, No. 2, (Desember, 2002), 183. 


\section{Da'wah bi al-Hal}

Pada dasarnya, diutusnya Rasulullah Muhammad tidak hanya mengemban misi keagamaan, tapi Rasulullah diutus untuk menjalankan misi kemanusiaan yang diamanatkan oleh Allah, yaitu untuk mengangkat nilainilai dan merubah pola hidup umat manusia. ${ }^{26}$

Salah satu metode yang bisa digunakan dalam berdakwah adalah da'wah bi al-hal atau dakwah dengan aksi nyata, ${ }^{27}$ atau menurut Quraish Shihab (dalam Mahmudin) disebut "dakwah pembangunan". ${ }^{28}$

Da'wah bi al-hal merujuk kepada ungkapan lisan al-bal afshahu min lisan al-maqal (bicara realitas keadaan, lebih berkesan daripada bicara yang diucapkan). Pada hakikatnya da'wah bi al-hal adalah pelaksanaan da'wah bi alamal (tindakan nyata). Dengan kata lain da'wah bi al-hal adalah dakwah yang dilakukan melalui penampilam kualitas peribadi dan aktivitas-aktivitas yang secara langsung menyentuh keperluan masyarakat. Mejar Burhanuddin Abdul Jalal menyatakan, da.wah bi al-hal sebagai satu metode dakwah sosial. Menurut Ali Yaakub Matondang, metode dakwah ini merupakan alternatif model dakwah dalam menyelesaikan persoalan sosial kemasyarakatan, misalnya persoalan sosial yang muncul karena permasalan ekonomi harus diselesaikan melalui pemenuhan kebuhuan ekonomi. Mereka membutuhkan sesuatu yang riil dan mendesak. Artinya, mereka butuh bantuan, pembinaan, dan bimbingan yang kongkret. ${ }^{29}$

Secara harfiah da'wah bi al-hal berarti menyampaikan ajaran Islam dengan amaliah nyata dan bukan tandingan da'wah bi al-lisan tetapi saling melengkapi antara keduanya. ${ }^{30}$

Ali Aziz megartikan da'wah bi al-hal: metode pemberdayaan masyarakat, yaitu dakwah dengan upaya untuk membangun daya, dengan cara mendorong, memotiviasi, dan membangkitkan kesadaran akan potensi yang dimiliki serta berupaya untuk mengembangkannya dengan dilandasi proses kemandirian. ${ }^{31}$

Dalam pengertian lebih luas da'wah bi al-hal, dimaksudkan sebagai keseluruhan upaya mengajak orang secara sendiri-sendiri maupun berkelompok untuk mengembangkan diri dan masyarakat guna mewujudkan tatanan sosial ekonomi dan kebutuhan yang lebih baik menurut tuntunan

${ }^{26}$ Muhammad 'Isham Hadziq, Irsyad al-Mu'minin. (Jombang: Maktabah al-Turats al-Islami, 1418H.), 5-6.

${ }^{27}$ Aziz, Imu Dakwah, 378.

${ }^{28}$ Mahmudin, "Strategi Dakwah Terhadap Masyarakat Agraris", Jurnal Dakwah Tabligh, Vol. 14, No. 1, (Juni, 2013), 104.

${ }^{29}$ Faizal, "Dakwah bil-Hal", 4.

${ }^{30}$ Suisyanto, "Dakwah bil-Hal", 184.

${ }^{31}$ Aziz, Ilmu Dakwah, 378 
Islam, yang berarti banyak menekankan pada masalah kemasyarakatan seperti kemiskinan, kebodohan, keterbelakangan dengan wujud amal nyata terhadap sasaran dakwah. ${ }^{32}$

Lebih lanjut, dakwah bi al-hal adalah dakwah yang lebih fokus pada amal usaha atau karya nyata yang bisa dinikmati dan bisa mengangkat harkat, martabat, dan kesejahteraan hidup kelompok masyarakat. Penekanan metode dakwah ini adalah perbuatan nyata, tujuannya adalah agar mad'u mengikuti jejak dan hal-ihwal da'i. Dakwah jenis ini mempunyai pengaruh yang besar pada diri mitra dakwah (mad'u). Pada saat pertama kali Rasulullah tiba di kota Yatsrib (Madinah), beliau mencontohkan da'wah bi al-bal ini dengan mendirikan Masjid Quba dan mempersatukan kaum Anshar dan Muhajirin dalam ikatan ukhuwah Islamiyah. Saat mendirikan masjid Quba, Rasul menjadi subyek pembangunan, para pengikutnya bekerja bukan karena perintah atau ceramah, tetapi melihat teladan. ${ }^{33}$

\section{Daerah Terpencil}

\section{Pengertian Daerah Terpencil}

Berdasarkan Kepmenkes 949 tahun 2007, daerah terpencil adalah daerah yang sangat sulit dijangkau karena berbagai sebab seperti keadaan geografis (kepulauan, pegunungan, daratan, hutan dan rawa. ${ }^{34}$

Menurut Murni Himawati, daerah terpencil adalah kawasan yang terisolasi dari pusat pertumbuhan/daerah lain akibat tidak memiliki atau kekurangan sarana (infrastruktur) perhubungan, sehingga menghambat pertumbuhan/perkembangan kawasan. ${ }^{35}$

\section{Karakteristik Daerah Terpencil}

Suatu daerah bisa dikategorikan pada kawasan terpencil apa bila: daerah perdesaan (unit administrasi desa); sarana/infrastruktur aksesibilitas kurang/tidak ada: jalan, jembatan; secara geografis jauh dari pusat pertumbuhan; ada isolasi geografis yang memisahkan dari daerah lain. ${ }^{36}$

\section{Kondisi Sosial Masyarakat Terpencil}

\footnotetext{
32 Suisyanto, "Dakwah bil-Hal", 184.

${ }^{33}$ Faizal, "Dakwah bil-Hal", 3.

34 Radinal Husein, "Studi Evaluasi Ketersediaan Tenaga Kesehatan Di Puskesmas Pada Kabupaten/Kota Daerah Tertinggal, Perbatasan Dan Kepulauan Terhadap Capaian Indikator Kinerja Standar Pelayanan Minimal Kabupaten Kota", (Tesis-Universitas Indonesia, Depok, 2013), 20.

${ }^{35}$ Himawati, Murni, "Manajemen Pendayagunaan Dana Wakaf Untuk Pembangunan Sarana dan Prasarana Desa Terpencil Pada Badan Wakaf Al-Qur'an Jakarta", (Skripsi-UIN Syarif Hidayatullah, Jakarta, 1433 H./2014 M.), 40.

${ }^{36}$ Ibid, 41.
} 
Melihat definisi dan karakteristik di atas, Mahmudin menggambarkan kondisi sosial masyarakat desa (terpencil). Menurutnya, masyarakat terpencil itu: lingkungan alam masih besar peranan dan pengaruhnya terhadap kehidupan masyarakat pedesaan; mata pencaharian bercorak agraris dan relatif homogen (bertani, beternak, nelayan, dll); corak kehidupan sosialnya bersifat gemain schaft (paguyuban dan memiliki community sentiment yang kuat); keadaan penduduk (asal-usul), tingkat ekonomi, pendidikan dan kebudayaannya relatif homogen; interaksi sosial antar warga desa lebih intim dan langgeng serta bersifat familistik; memiliki keterikatan yang kuat terhadap tanah kelahirannya dan tradisi-tradisi warisan leluhurnya; masyarakat desa sangat menjunjung tinggi prinsip-prinsip kebersamaan/gotong royong kekeluargaan, solidaritas, musyawarah, kerukunan dan keterlibatan sosial; jumlah warganya relatif kecil dengan penguasaan IPTEK relatif rendah, sehingga produksi barang dan jasa relatif juga rendah; pembagian kerja dan spesialisasi belum banyak dikenal, sehingga deferensiasi sosial masih sedikit; kehidupan sosial budayanya bersifat statis, dan monoton dengan tingkat perkembangan yang lamban; masyarakatnya kurang terbuka, kurang kritis, pasrah terhadap nasib, dan sulit menerima unsur-unsur baru; memiliki sistem nilai budaya (aturan moral) yang mengikat dan dipedomani warganya dalam melakukan interaksi sosial. Aturan itu umumnya tidak tertulis; penduduknya bersifat konservatif, tetapi sangat loyal kepada pemimpinnya dan menjunjung tinggi tata nilai dan norma-norma yang berlaku. ${ }^{37}$

Selain itu, mengutip pendapat Landisi, kondisi sosial masyarakat terpencil itu: umumnya mereka "curiga" terhadap orang luar yang masuk; para orang tua umumya otoriter terhadap anak-anaknya; cara berfkir dan sikapnya konservatif dan statis; mereka amat toleran terhadap nilai-nlai budayanya sendiri, sehingga kurang toleran terhadap budaya lain; adanya sikap pasrah menerima nasib dan kurang kompetitif; memiliki sikap kurang komunikatif dengan kelompok sosial diatasnya. ${ }^{38}$

Seluruh ciri atau karakteristik di atas sangat berpengaruh terhadap konsep berdakwah. Bagaimana seorang dai dapat menyesuaikan metode dakwahnya dengan keadaan mad'u yang cenderung menerima sikap pasrah dan kurang komunikatif dengan orang golongan di atasnya. ${ }^{39}$

Kondisi masyarakat sebagaimana disebutkan di atas rata-rata tingkat pendidikannya rendah, karena kurangnya aksesibilitas; tingkat ekonomi

\footnotetext{
${ }^{37}$ Mahmudin, "Strategi Dakwah Terhadap Masyarakat Agraris", Jurnal Dakwah Tabligh, Vol. 14, No. 1 (Juni, 2013), 107-108.

38 Ibid, 108.

${ }^{39}$ Ibid.
} 
menengah ke bawah, karena kegiatan ekonomi yang tidak merata; masih menggantungkan hidupnya pada sumber daya alam.

Selain itu, masyarakat terpencil cenderung ekslusif (tertutup), tidak dapat membedakan antara hal-hal yang bersifat ajaran dan non-ajaran, cenderung tekstualis-literalis, cenderung kurang menghargai waktu, cenderung tidak mempermasalahkan tradisi yang terdapat dalam agama, cenderung tidak mengutamakan perasaan dari pada akal pikiran, cenderung bersifat jabariah dan teosentris, kurang menghargai ilmu pengetahuan dan teknologi modern, jumud dan statis. Kondisi masyarakat masyarakat yang cenderung memiliki waktu yang terbatas di waktu malam dan lebih banyak bekerja pada siang hari serta lebih banyak di rumah pada malam hari, ${ }^{40}$ maka metode dakwah yang strategis adalah dakwah melalui karya nyata, karena jika, misalnya, menggunakan metode bi al-lisan, mereka memiliki waktu yang terbatas; jika, misalnya, menggunakan metode bi al-qalam, tingkat pendidikan mereka tergolong rendah, sehingga pesan dakwah tidak dapat merata. Maka dari itu, metode da'wah bi al-hal sangat pas untuk menyampaikan pesan-pesan agama.

\section{Dakwah bi al-Hal Dalam al-Qur'an}

Berkenaan dengan hal ini, banyak ayat-ayat al-Qur'an yang berbicara tentang kegiatan dakwah bi al-hal, di antaranya adalah ayat-ayat berikut:

1. QS. Fushilat (41): 33 yang artinya:

"Dan siapakah yang lebih baik perkataannya dari pada orang yang menyeru kepada Allah dan yang telah mengerjakan amal shaleh dan berkata 'sesunggubnya aku termasuk. orang yang berserah diri."

Quraish Shihab (dalam Faizal), menafsirkan ayat ini, bahwa perkataan terbaik (absanu qaulan) adalah ajakan tauhid (mengesakan Allah), menyembah Allah, taat kepadaNya secara tulus. Menyampaikan seruannya setelah mengerjakan amal yang shaleh. Sehingga, seruannya semakin mantap, baik kepada kawan dan lawan yang taat maupun durhaka. ${ }^{41}$

Lebih lanjut lagi, Faizal memaparkan bahwa, berdasarkan penafsiran tersebut, jelas da'wah bi al-hal (kerja dan karya nyata) merupakan suatu keniscayaan, karena da'i akan lebih percaya diri dalam menyampaikan pesan dakwah atau ide-ide perubahan dan mad'u akan lebih terkesan dan akan melakukan pengembangan diri sesuai dengan da'wah qudwah (suri teladan) da'i. Mencontohkan keberhasilan merupakan motivasi untuk berkarya, baik bagi seorang da'i maupun bagi mitra dakwah. ${ }^{42}$

\footnotetext{
${ }^{40}$ Ibid, 111.

${ }^{41}$ Faizal, "Dakwah bil-Hal”, 5.

${ }^{42}$ Ibid.
} 
Selain itu, juga merupakan isyarat bahwa materi yang disampaikan dalam da'wah bil-hal adalah materi yang berhubungan dengan perubahan dalam segala aspek kehidupan manusia yang kemudian didukung oleh materi pengembangan nilai-nilai moral, seperti; ketauhidan, ibadah, dan akhlak. ${ }^{43}$

2. QS. al-Ra'd (13): 11

"Sesunggubnya Allah tidaklah akan mengubah apa yang ada pada suatu kaum, sehingga mereka mengubah apa yang ada pada diri mereka sendiri, jika Allah bendak. mendatang celaka kepada suatu kaum, maka tidak ada penangkalnya. Dan, selain dari pada-Nya tidak ada pelindung".

Secara harfiah, ayat di atas menunjuk pada suatu makna, bahwa Allah tidak akan merubah keadaan suatu kaum kecuali kaum itu sendiri yang terlebih dahulu berupaya merubah nasibnya. Makna tersebut berarti, Allah SWT akan memberikan jalan kepada perubahan apabila ada ikhtiar atau usaha merubah nasib mereka kepada yang lebih baik, mempertinggi mutu diri dan mutu amal, melepaskan diri dari perbudakan selain Allah. Manusia harus berusaha untuk mencapai taraf kehidupan yang lebih baik. Namun demikian, perlu disadari bahwa, seorang hamba tidak boleh lupa akan adanya takdir yang telah ditetapkan Allah.

Apabila seorang hamba tidak taat kepada Allah, maka ia tidak akan mampu mencapai tujuan hidup kepada keadaan yang lebih baik, melainkan tertimpa celaka. Hal ini sejalan dengan pendapat al-Qasyani, yang dikutip oleh Hamka: "tidak dapat tidak, keadaan bisa saja berubah dari ni'mat (karunia) menjadi niqmat (tertimpa celaka, baik yang nyata maupun yang tersembunyi". ${ }^{44}$

Penjelasan di atas, secara implisit mengisyaratkan bahwa, tujuan dakwah bi al-hal adalah sama dengan tujuan pemberdayaan atau pengembangan masyarakat, yakni mengedepankan keinginan, upaya dan partisipasi masyarakat untuk melakukan perubahan.

\section{Da'wah bi al-Hal: Upaya Memberdayakan Mad'u}

Secara konseptual pemberdayaan atau pemberkuasaan (empowerment) berasal dari kata power (kekuasaan atau keberdayaan). Konsep mengenai kekuasaan merupakan ide utama dalam hal pemberdayaan. Kekuasaan sendiri selalu diartikan sebagai kemampuan untuk mengatur orang lain sesuai dengan yang diinginkan. Pemberdayaan berdasarkan perspektif sosiologi adalah menampilkan peran-peran aktif dan kolaboratif antara masyarakat dan mitranya.

\footnotetext{
43 Ibid.

${ }^{44}$ Ibid, 6.
} 
Adanya kerja sama yang saling berkesinambungan dan melaksanakan tugasnya masing-masing. ${ }^{45}$ berikut: ${ }^{46}$

Adapun tujuan, proses dan cara-cara pemberdayaan adalah sebagai

1. Pemberdayaan bertujuan untuk meningkatkan kekuasaan orang-orang yang lemah atau tidak beruntung;

2. Pemberdayaan adalah sebuah proses yang menyebabkan orang lain menjadi cukup kuat untuk berpartisipasi dalam berbagai pengontrolan atas dan memmengaruhi terhadap kejadian-kejadian serta lembaga-lembaga yang dipengaruhi kehidupannya. Pemberdayaan menekankan bahwa orang memperoleh keterampilan, pengetahuan dan kekuasaan yang cukup untuk mempengaruhi kehidupannya dan kehidupan orang lain yang menjadi perhatiannya;

3. Pemberdayaan merujuk pada usaha pengalokasian kembali kekuasaan melalui pengubahan struktur sosial;

4. Pemberdayaan adalah suatu cara yang menjadikan rakyat, organisasi dan komunitas diarahkan agar mampu menguasai (atau berkuasa atas) kehidupannya.

Ketika Nabi Muhammad berada di Mekkah, pengikutnya hanya dua puluh lima orang saja secara keseluruhan yang berasal dari kelompok kaya dan bangsawan. Selebihnya berasal dari kelompok-kelompok miskin. Bahkan yang paling dahulu masuk Islam kebanyakan adalah orang-orang miskin, orang-orang gembel, para budak, dan sebagainya. ${ }^{47}$

Sepanjang hidupnya Rasulullah SAW. selalu berpihak pada kelompok golongan lemah dalam menghadapi kelompok-kelompok kuat. Menurut alQur'an, orang yang tidak menyantuni para dlu'afa' atau mustadl'afin disebut orang yang mendustakan agama (yukadrdribu bi al-din) kadang-kadang al-Qur'an menyebut mereka pencemooh. ${ }^{48}$

Secara sepintas, sikap keberpihakan Rasulullah kepada dbu'afa' dan mustadl'afin ini bisa dikategorikan pada da'wah bi al-hal. Pun begitu sebagaimana dijelaskan oleh al-Qur'an.

Ruang lingkup da'wah bi al-hal meliputi semua persoalan yang berhubungan dengan kebutuhan pokok (basic needs) manusia, terutama yang berkaitan dengan kebutuhan fisik material ekonomis, maka kegiatan da'wah bi alhal lebih menekankan pada pengembangan kehidupan dan penghidupan

45 Asep Iwan Setiawan, "Dakwah Berbasis Pemberdayaan Ekonomi dan Peningkatan Kesejahteraan Mad'u", Jurnal Ilmu Dakwah, Vol. 6, N0. 20, (Juli-Desember, 2012), 349.

46 Ibid.

47 Ali Hasan Siswanto, Dialektika Tradisi NU di Tengah Arus Modernisasi (Surabaya: IQ_Media, 2014), 38.

${ }^{48}$ Ibid, 38-39. 
masyarakat dalam rangka meningkatkan taraf hidup yang lebih baik sesuai dengan tuntunan ajaran Islam. Bentuk-bentuk pengembangan kegiatan da'wab bi al-bal dapat dilakukan melalui bentuk pengembangan kehidupan dan penghidupan manusia antara lain berupa: ${ }^{49}$

a. Penyelenggaraan pendidikan pada masyarakat;

b. Kegiatan koperasi;

c. Pengembangan kegiatan transmigrasi;

d. Penyelenggaraan usaha kesehatan masyarakat seperti mendirikan rumah sakit, Poliklinik, BKIA, balai pengobatan, dan sebagainya;

e. Peningkatan gizi masyarakat;

f. Penyelenggaraan panti asuhan;

g. Penciptaan lapangan kerja;

h. Peningkatan penggunaan media cetak, media informasi dan komunikasi serta seni budaya.

Menurut Suisyanto, da'wah bi al-hal tidak hanya sekedar usaha peningkatan kesejahteraan materiil semata, termasuk ke dalam kegiatan dakwah bi al-hal adalah usaha pemenuhan dan peningkatan kebutuhan serta kesejahteraan non materiil, yakni usaha seperti meningkatkan kualitas pengamalan ibadah, al-akblaq al-karimah dengan pengembangan sumber daya manusia. ${ }^{50}$

Dengan melihat luasnya ruang lingkup da'wah bi al-hal maka dalam pelaksanaannya diperlukan keterpaduan program, perencanaan pelaksanaan dan evaluasi dengan berbagai instansi terkait, berbagai tenaga ahli dan disiplin ilmu. Ini artinya bahwa da'wah bi al-hal harus dilaksanakan secara totalitas dan berangkat dari akar permasalahan yang terjadi dalam masyarakat yang lebih dikenal dengan empowering atau pemberdayaan jamaah.

Metode da'wah bi al-hal, menurut Aziz, selalu berhubungan dengan tiga aktor: masyarakat (komunitas atau jamaah), pemerintah dan agen (dai). Menurutnya, melalui sinergitas ketiga aktor ini dai dapat mempersiapkan teknik dakwahnya. ${ }^{51}$

Dilihat dari posisi ini da'wah bi al-hal merupakan usaha menyampaikan ajaran Islam kepada umat dengan cara membantu mengatasi masalah yang dihadapinya. Masalah tersebut merupakan masalah hidup dan kehidupan umat, usaha pemecahan masalah ini berangkat dari akar masalah yang pada akhirnya umat itu sendiri mengatasi masalah mereka dengan dasar kesadaran, sumbersumber daya yang mereka miliki digali, dimobilisir, diorganisir untuk memenuhi kebutuhan. Ini artinya bahwa dakwah merupakan usaha memanusiakan manusia (manusia seutuhnya). Secara rohani menumbuhkan kesadaran membangun dan

\footnotetext{
49 Suisyanto. "Dakwah bil-Hal", 187.

${ }^{50}$ Ibid, 188.

${ }^{51}$ Aziz, Ilmu Dakwah, 378.
} 
jasmaninya memunculkan tindakan-tindakan yang nyata dalam pembangunan. Dalam hal ini lebih merupakan fasilitator (agen) dalam pelaksanaan pembangunan tersebut, artinya dari sebagai pembuka pintu pembangunan yang akan memunculkan perubahan-perubahan yang dilakukan oleh umat. Hal ini dikarenakan dakwah memiliki sifat taghyir (perubahan) yang muncul dari, oleh, dan untuk jamaah. Sebagaimana Rasulullah bersabda bahwa makanan terbaik untuk dimakan oleh seseorang adalah hasil jerih payah usahanya sendiri. Ini artinya bahwa pemecahan masalah seseorang atau suatu kelompok orang -akan sangat arif dan bermanfaat bagi mereka- jika mereka sendiri yang mencari pemecahannya, orang lain $\left(d a^{\prime} i\right)$ hanya membantu, tidak sebagai pelaku utama. ${ }^{52}$

Untuk menggali kesadaran jamaah dan meningkatkan pengembangan potensinya, dapat dipergunakan formula pengembangan swadaya masyarakat melalui tahapan sebagai berikut: ${ }^{53}$

1) Mengajak jamaah untuk mengenali dan memahami masalah mereka sendiri;

2) Menumbuhkan keinginan jamaah untuk berperan aktif mencari alternatif pemecahan masalah (sebuah perencanaan awal);

3) Persiapan jamaah dalam pelaksanaan pemecahan masalah (perencanaan matang);

4) Penyebarluasan metode-metode swadaya jamaah;

5) Evaluasi dan follow up (tindak lanjut).

Lebih umum lagi, Ali Aziz memparkan tahapan-tahapan teknik dalam rangka dakwah karya nyata, sebagaimana berikut: ${ }^{54}$

a) Teknik non-partisipasi. Bentuknya adalah dari pemerintah, oleh pemerintah, untuk rakyat. Dalam hal ini, masyarakat sifatnya pasif dan hanya menjadi objek program intervensi yang telah dirancang dan diimplementasikan. Pemerintah sebagai dinamisator dan agen dakwah sebagai evaluator;

b) Teknik tokenisme. Bentuknya adalah dari pemerintah bersama rakyat untuk rakyat. Masyarakat seolah-olah diberi ruang partisipasi dengan menyampaikan pendapat, saran dan keberatan, namun sesungguhnya hanya formalitas belaka. Pemerintah berperan sebagai katalisator dan agen dakwah sebagai implementator;

c) Teknik partisipasi/kekuasaan masyarakat. Bentuknya adalah dari rakyat, oleh rakyat, untuk rakyat. Masyarakat telah mendapatkan tempat dalam suatu program pembangunan. Sejak perencanaan hingga evaluasi dilakukan oleh rakyat secara mandiri. Pemerintah hanya sebagai fasilitator, dan agen dakwah sebagai pendamping. Teknik-teknik partisipasi ini dapat diuraikan sebagai berikut:

\footnotetext{
52 Suisyanto. "Dakwah bil-Hal”, 188-189.

53 Ibid, 189-190.

${ }^{54}$ Aziz, Ilmu Dakwah, 378-381.
} 
- Secondary Data Review (SDR): mengumpulkan sumber-sumber informasi yang telah diterbitkan maupun belum disebarkan untuk mengetahui data yang ada;

- Direct Observation: melihat secara langsung pada objek-objek tertentu, kejadian, proses, hubungan-hubungan masyarakat, serta mencatatnya;

- Semi Structured Interviewing (SSI): wawancara yang menggunakan panduan pertanyaan sebagai rujukan untuk mengembangkan pertanyaan lebih lanjut;

- Focus Group Discussion (FGD): diskusi antara beberapa orang untuk membicarakan hal-hal yang bersifat khusus secara lebih mendalam;

- Preference Ranking and Scoring: menentukan secara cepat problem-problem utama dan pilihan masyarakat;

- Pairwise Ranking: membuat rangking dan semua yang berkaitan dengan hidup masyarakat secara individual, untuk memahami masalah utama dan pilihan individu;

- Direct Matrix Ranking: bentuk rangking yang mengidentifikasi daftar kriteria objek tertentu, agar bisa memahami alasan-alasan terhadap pilihan-pilihan masyarakat;

- Wealth Ranking: rangking kesejahteraan masyarakat di suatu tempat tertentu, agar memperoleh gambaran profil kondisi masyarakat;

- Mobolity Mapping: alat untuk menggambarkan hubungan masyarakat dengan pihak luar, untuk mencatat, membandingkan, dan menganalisis mobilitas dari berbagai kelompok masyarakat;

- Social Mapping: cara membuat gambar kondisi fisik sosial ekonomi masyarakat;

- Transect: teknik penggalian informasi dan media pemahaman daerah melalui penelusuruan dengan berjalan mengikuti garis yang membujur dari suatu sudut ke sudut lain di wilayah tertentu;

- Seasonal Calender: penelusuran kegiatan musiman tentang keadaan dan permasalahan yang berulang-ulang dalam kurun waktu tertentu di masyarakat;

- Time Line (Trends and Historical Profile): mengetahui kejadian-kejadian dari suatu waktu sampai keadaan sekarang dengan persepsi orang setempat;

- Livelihood Analysis: alat analisis mata pencaharian masyarakat untuk panduan diskusi tentang kehidupan mereka dan mata pencaharian;

- Flow/Causal Diagram: menggambarkan hubungan antara masalah yang satu dengan yang lain berupa kaitan sebab dan akibat;

- Venn Diagram: mengetahui hubungan institusional dengan masyarakat, agar pengaruh institusi tersebut dapat diketahui;

- Farm Sketch: gambaran mengenai bentuk tipikal pengelolaan lingkungan sebagai percontohan;

- Trends and Change: mengungkapkan kecenderungan dan perubahan yang terjadi di masyarakat dalam jangka tertentu;

- Daily Routine Diagram: diagram yang menggambarkan kegiatan sehari-hari dari anggota masyarakat;

- Historical Profile: mengumpulkan kejadian-kejadian penting masa lalu di masyarakat yang sampai sekarang ada bekas-bekasnya. 
Langkah-langkah sebagaimana dipaparkan di atas merupakan suatu pedoman dalam melaksanakan kegiatan da'wah bi al-hal yang bertujuan untuk mengangkat taraf kehidupan mad'u menjadi lebih baik.

\section{Penutup}

Sebagai agama dakwah, Islam sangat menekankan nilai-nilai kemanusiaan. Islam mengajarkan kepada umatnya untuk menjadi pribadi yang selalu berbuat baik, tidak hanya untuk dirinya sendiri, tapi juga untuk orang lain. Oleh karenanya, Islam mewajibkan bagi setiap pemeluknya untuk turut andil dalam kegiatan dakwah demi tersebarnya ajaran dan nilai-nilai Islam.

Selama ini, dakwah diartikan secara sempit. Dakwah hanya dianggap sebagai suatu aktifitas mengajak dan menyeru yang dikonotasikan pada penyampaian ajaran agama berupa ayat-ayat dan hadits saja. Lebih ironis lagi, ketika seseorang melakukan suatu kebaikan, tanpa dibubuhi ayat-ayat al-Qur'an dan Hadits yang berbahasa Arab tidak dianggap dakwah. Padahal, dalam kondisi masayarakat yang jenuh dengan materi dakwah yang bermuatan motivasi, hukuman dan ganjaran tanpa adanya jalan keluar yang konkrit.

Sebagai seorang muslim, tidak bisa tinggal diam melihat kesenjangan yang terjadi di sekitarnya. Seorang muslim dituntut untuk menyebarkan ajaran agama Islam sehingga eksistensi Islam bisa dirasakan oleh semua makhluk, karena agama ini merupakan bentuk kasih sayang Allah kepada seluruh alam (rahmatan lil 'alamin).

Untuk merubah kesenjangan yang terjadi di masyarakat, tidak cukup hanya dengan menyampaikan term-term normatif (al-Qur'an dan Hadits) saja, tapi harus ada karya nyata dalam mengatasi kondisi tersebut. Karya nyata inilah yang disebut dengan da'wah bi al-hal.

Metode da'wah bi al-hal ini pertama kali diimplementasikan oleh Rasulullah sewaktu beliau sampai ke Yatsrib saat membangun Masjid Quba. Saat proses pembangunan berlangsung, Rasulullah turun langsung, berbaur dan bekerja bersama para sahabat lain menyelesaikan bangunan masjid itu. Dari sini Rasulullah berhasil menyatukan dua kelompok sahabat (anshar dan muhajirin) dengan ukhuwah Islamiyah, hingga dua kelompok sahabat ini menjadi satu kesatuan ibarat tubuh manusia: satu sakit, yang lain juga merasa sakit. Sifat seperti inilah yang harus dimiliki oleh seorang dai. Harus peka dan sensitif terhadap kondisi sosial. 


\section{DAFTAR PUSTAKA}

Abduh, Muhammad. Komitmen Dai Sejati, terj. Asep Sobri. Jakarta: Al-I'tishom Cahaya Umat, 2007.

Aswadi. Dakwah Progresif Perspektif Al-Qur'an. Sidoarjo: Dwiputra Pustaka Jaya, 2016.

Aziz, Jum'ah Amin Abd. al-Da'wah: Qawaid wa Ushul. Alexandria: Dar al-Da'wah, 1999 M./1419 H.

Aziz, Moh. Ali, Ilmu Dakwah. Jakarta: Kencana, 2016.

Bayanuni (al), Muhammad Abu al-Fath. al-Madkhal ila Tlmu al-Da'wah. Beirut: Mu'assasah al-Risalah, 2001 M./1422 H.

Faizal. "Dakwah bil-Hal Dalam Perspektif Al-Qur'an", Jurnal Ilmu Dakwah dan Pengembangan Komunitas, Vol. VIII, No. 2, Juli, 2013.

Hadziq, Muhammad 'Isham. Irsyad al-Mu'minin. Jombang: Maktabah al-Turats al-Islami, $1418 \mathrm{H}$.

Himawati, Murni. "Manajemen Pendayagunaan Dana Wakaf Untuk Pembangunan Sarana dan Prasarana Desa Terpencil Pada Badan Wakaf Al-Qur'an Jakarta". Skripsi-UIN Syarif Hidayatullah, Jakarta, 1433 H./2014 M.

Mahmudin. "Strategi Dakwah Terhadap Masyarakat Agraris", Jurnal Dakwah Tabligh, Vol. 14, No. 1, Juni, 2013.

Mubasyaroh. "M. Natsir dan Pandangannya Tentang Dakwah Dalam Buku Fiqhud Dakwah", At-Tabsyir, Vol. 1, No. 2, Juli-Desember, 2013.

Munawwir, Ahmad Warson. Al-Munawnir: Kamus Arab-Indonesia. Surabaya: Pustaka Progresif, 1984.

Novaili. "Metode Dakwah Penyuluh Agama Islam Dalam Mewujudkan Keluarga Sakinah Terhadap Pasangan Calon Suami Istri Di Kantor Urusan Agama (KUA)", Konseling Religi, Vol. 6, No. 2, Desember, 2015. Prasti, Rizka. "Dakwah Melalui Media Radio (Analisis Pogram Cahaya Pagi di Radio Alaikassalam Sejahtera Jakarta)". Skripsi-UIN Syarif Hidayatullah, Jakarta, 2010 M./1432 H.

Priyanto, Edy. "Dakwah dan Kesalehan Sosial: Kiprah Dakwah Roostien Ilyas". Skripsi-UIN Syarif Hidayatullah, Jakarta, 1436 H./2015 M.

Radinal Husein, "Studi Evaluasi Ketersediaan Tenaga Kesehatan Di Puskesmas Pada Kabupaten/Kota Daerah Tertinggal, Perbatasan Dan Kepulauan Terhadap Capaian Indikator Kinerja Standar Pelayanan Minimal Kabupaten Kota”. Tesis—Universitas Indonesia, Depok, 2013.

Razi, Fahrur. "NU dan Kontinuitas Dakwah Kultural", Jurnal Komunikasi Islam, Vol. 1, No. 2, Desember, 2011.

Setiawan, Asep Iwan. "Dakwah Berbasis Pemberdayaan Ekonomi dan Peningkatan Kesejahteraan Mad'u", Jurnal Ilmu Dakwah, Vol. 6, N0. 20, Juli-Desember, 2012. 
Siswanto, Ali Hasan. Dialektika Tradisi NU di Tengah Arus Modernisasi. Surabaya: IQ_Media, 2014.

Suisyanto. "Dakwah bil-Hal (Suatu Upaya Menumbuhkan Kesadaran dan Mengembangkan Kemampuan Jamaah)", Aplikasia, Vol. 3, No. 2, Desember, 2002.

Syam, Yunus Hanis \& Muafi. Manajemen Dakwah: Dakwah dengan Tulisan Sebuah Peluang. Yogyakarta: Panji Pustaka, 2007.

Wisri. "Dakwah Pada Masyarakat Terasing: Studi Analisis tentang Tipologi Mitra Dakwah "Suku Anak Dalam" di Taman Nasional Bukit Dua Belas Jambi”, Jurnal Lisan Al-Hal, Vol. 6, No. 1, Juni, 2014 